Open Access

\title{
Implementing open innovation concept in social business
}

\author{
Anna Svirina ${ }^{1 *}$, Alfia Zabbarova ${ }^{1}$ and Karine Oganisjana ${ }^{2}$
}

\author{
* Correspondence: \\ anna_svirina@list.ru \\ ${ }^{1}$ Economics and Management \\ Department, Chistopol autonomous \\ campus, Kazan National Research \\ Technical University, Kazan, Russia \\ Full list of author information is \\ available at the end of the article
}

\begin{abstract}
Social business is an emerging concept which requires additional research especially in terms of priority management tools that can be used. The paper aims to evaluate how closed and open innovation concepts are implemented by social enterprises in the emerging information economy. The paper also studies social enterprises from the point of view of joint efficiency and innovation development concept evaluation to define best practices used by social entrepreneurs nowadays.

The paper provides comparative analysis of two types of social business models: the ones based on open innovation and the ones based on formal closed innovative process. Research question is to estimate how implementation of open innovation influences social businesses' outcomes, and to define the way open innovation influences social enterprises' efficiency.
\end{abstract}

Keywords: Open innovation, Social business, Business model, Innovation process, Quantum economics

\section{Introduction}

Existing literature have provided quite a number of on business concepts which are successful under different types of regulation, and various basements which an entrepreneur can use to build a successful model. As in the beginning of XXI century the variety of business models increased, some of researchers outlined the importance of institutions and their influence on entrepreneurial development (de Soto 2000), the need for value creation (Porter \& Cramer 2011, Driver 2012), businesses which used poverty as an inspiration to build up economically efficient model (Yunus 2008), and new trends in business model development arising from the network economy (Benkler 2006). These scholars all came to a similar conclusion: business models which are proposed normally do not consider societal effects - and therefore fail to capture an important market (Yunus 2008), ignore societal opportunity (Driver 2012), or substitute shared value creation for the implementation of socially responsible practices (Porter \& Cramer 2011). The majority of these critiques regard the development of social entrepreneurship as a means of changing this pattern.

The importance of social business in providing sustainable opportunities to solve major problems of the society, including poverty (Yunus 2008), the researchers started paying attention towards building understanding of success factors driving development of this entrepreneurship type. According to Dees (2001) and Yunus (2008) social entrepreneurship provides lower profits, then regular business, requires more sustainable models,

(C) 2016 The Author(s). Open Access This article is distributed under the terms of the Creative Commons Attribution 4.0 International License (http://creativecommons.org/licenses/by/4.0/), which permits unrestricted use, distribution, and reproduction in any medium, provided you give appropriate credit to the original author(s) and the source, provide a link to the Creative Commons license, and indicate if changes were made. 
leads to longer payback periods but at the same time has much more sustainable results and loyal customers. Still, restrictions that exist for social entrepreneurs call for more efficient business solutions, especially for competitive advantage development, which in turn requires evaluation of possibilities to use more efficient resources. The need to cut costs lead to more attention towards implementation of cost-saving models spread in regular business, such as a concept of open innovation (Chesbrough 2003); and this paper focuses on evaluation of the open innovation model as a tool to increase efficiency of social business.

The research question of this paper is to define how the use of open and closed innovation models affects development of social enterprise.

\section{Literature overview}

Dacin et al. (2010) indicated, that there are a number of approaches to define social entrepreneurship, starting from Waddock and Post (1991), Leadbeater (1997), Thomson et al. (2000), Dees (2001) to the present day. At the same time a number of studies had indicated that these definitions create more confusion than understanding (Masetti 2008; Dacin et al. 2010): scholars and practitioners have a very different view towards the contents and thus business models of social business (Austin et al. 2006, Hockerts 2006; Roberts \& Woods 2005; Yunus 2008; Santos 2012, Zahra et al. 2009; Grameen Creative Lab 2014, Schwab Foundation 2016 and Skoll Foundation 2016) at the same time stating no important differences between social and conventional entrepreneurship. The primary characteristics of social entrepreneurship as outlined by the scholars and practitioners are the following:

(1)its main goal is to drive important societal change (social mission);

(2)it implies exercising business processes and discipline, innovation, and determination in seeking business solutions to social problems;

(3) it entails the pursuit of economic efficiency;

(4) it is motivated by strong ethics;

(5)it involves the creation of value beyond resources currently under the entrepreneur's control.

However, all of these characteristics hold for any "conventional" entrepreneur, as identified by Schumpeter (1934), Kirzner (1978), Timmons and Spinelli (1990), Estrin et al. (2013) and others. On the other hand, practitioners have outlines some interesting differences:

(1)a social entrepreneur seeks to solve the problems created by institutions, which therefore cannot be solved by these same institutions (Ashoka 2014);

(2)the business's objective is to overcome poverty or another problem (such as education, health, technology access, and environment) that threatens individuals and society, not profit maximization (Grameen Creative Lab 2014);

(3) social entrepreneurs serve as society's change agents (Skoll Foundation 2016).

These differences indicate the need social entrepreneurs have to create more sustainable models operating in sectors where (a) the profit rate is lower than in conventional 
entrepreneurship and (b) existing institutions actually fail to solve the problem. An analogue of this situation is evaluated by Chesbrough (2003) and led to creation of open innovation concept, as this one is more efficient than existing legal frameworks that protect intellectual property on the one hand, and allows to seek opportunities at lower margins. Intuitively, such concept should be efficient for social entrepreneurs.

Researchers dealing with open innovation have identified that "corporate OI goes through evolutionary stages in the market, blooming into various types and levels of emergence, or being influenced by strange triggers, under complex adaptive systems." (Yun et al. 2016), which is in line with above mentioned suggestion that open innovation concept evolved through its efficiency, and creates higher adaptivity which is essential for development of social enterprise that operates at low profits. Moreover, Carillo (2015) had indicated, that development of new economic culture in emerging network information economy, is impossible without open innovation - and as social business seems to be an important element of network economy, the same concept has to be implemented.

Open innovation does not only increase efficiency of research and development activities, but, as suggested by Kim et al. (2016) and Yusr (2016) leads to higher efficiency in triple helix relationships, which operate in the public goods field and present the closest analogue of social entrepreneurs solving the problems of contemporary society in sustainable and profitable way. Finally, researchers in open innovation outline, that $\mathrm{CEO}$ in public sectors tend to implement open innovation concept in their managerial approaches, hence suggesting the idea to use a similar approach in any field where societal effects are important.

Still, despite existing relationship between social entrepreneurship and open innovation management, the field remains underdeveloped, and lead to need in focusing on importance of open innovation in social business development.

\section{Methodology}

For the purposes of this study we evaluate social enterprises which either use or do not use open innovation concept by using case study method to provide comparative analysis of innovation development and implementation practice in case open innovation and formal closed innovation process are used. The data is acquired from open sources including Ashoka, Grameen Lab, Skoll Foundation and web-sites of social innovation companies. This type of analysis aims to reveal the main differences in development paths of innovative social businesses.

Quantitative analysis is performed as well on the basis of cluster analysis to create typology of social businesses, including typology of social enterprises whose business model is based on open innovation concept. The data for this analysis was acquired as open source, coming from studies like Social business GEM report, Heritage foundation, Kaufmann foundation and others. Using this data we also perform regression analysis and graph analysis to see the patterns of social business development in case of use of open and closed innovation concepts. We evaluated sustainability of company performance as a dependent variable which relies on open innovation in social business. 


\section{Findings}

The role of institutions (including innovation regulation) had been discussed by scholars (Dacin et al. 2010; Estrin et al. 2013, Mair \& Marti 2006, Sud et al. 2009), who agree on the importance of the institutional setting for the development of social entrepreneurship - from indicating that social business models must operate in the institutional settings for which they were created (Dacin et al. 2010) to questioning the ability of social entrepreneurs to "provide comprehensive answers to the most pressing social ills" (Sud et al. 2009). We agree with Sud et al. (2009) and regard social business as just one approach to social and economic development (as outlined in the definition above), based on opportunities that were overlooked by conventional entrepreneurs (Yunus 2008). We also base our understanding on the findings of Dacin et al. (2010), who noted that "social entrepreneurship is more likely to occur where there are significant socioeconomic, cultural and environmental problems". Empirical research offers a similar perspective: "social entrepreneurship in some developing countries is likely to be shaped by the political context and the heritage of weak governments" (Terjesen et al. 2009). In these contexts, social market failure creates an opportunity for a social entrepreneur (Austin et al. 2006) and thus allows for the creation of new social value (Urbano et al. 2010). Nevertheless, these arguments, despite appearing perfectly logical, are not supported by certain empirical analyses. Stephan et al. (2014) reported that the development of revenue-generating social business is only strongly associated with government activism and the rule of law, and these two features are rarely observed in economies with weak institutions.

A number of authors suggested that institutional environment is one of the major factors which define the level of social entrepreneurial activity, providing detail on reasoning behind this influence. These details include effectiveness of government actions and the quality of infrastructure (Partzsh \& Ziegler 2011), cultural preferences (Montgomery et al. 2012), poverty level (Yunus 2008), and other features which differ for different countries (Peattie and Morley 2008).

To resolve this contradiction, we suggest the following approach to define how institutions influence organizations with social missions: (1) the form of these organizations is influenced by the type of institutions that prevail in the context in which a social entrepreneur perceives an opportunity - and these institutions can be either formal or informal - and (2) the type of organization is defined by the average level of regulatory control and rule of law (relative to those of other countries) that exist in a country (in the case of highly polarized countries, the regional level should also be considered as a moderator). The matrix mapping social business onto these two axes can be found in Fig. 1.

As it is seen from the Figure, social entrepreneurs tend to evolve in the areas with lower regulation and control performed by the government. In case of innovation implementation this means such business owners would try to avoid formal intellectual property regulation and develop their businesses on the basis of open concepts. As the case study indicates, such approach is used by a number of social businesses (see Table 1).

As indicated in a table, a number of social enterprises are using open innovation concept, as defined by Chesbrough \& Vanhaverbeke (2006), when some technologies or approaches are developed within community and spread over thus enhancing feedback 


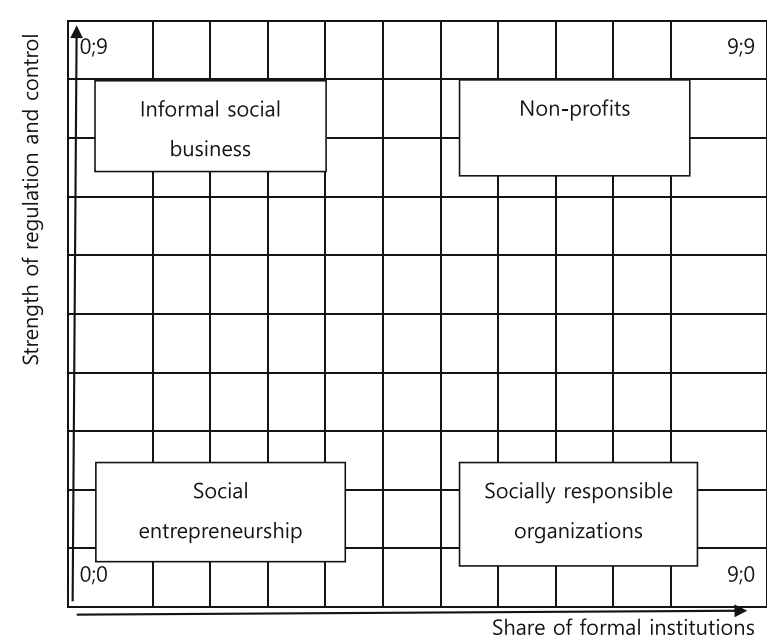

Fig. 1 Matrix of businesses with social mission on immature state of the key market (developed by the authors)

and evaluation of technology. For instance, Grameen Danone social business used Danone's innovative yogurt production technology (which was developed in accordance with special requirements of Bangladesh market), and Grameen's innovative distribution chain (which was developed under Grameen bank) - thus, both companies in their social business partnership were using each other's external innovation ideas and developments. The same innovation sharing can be found in Genesys Works (Genesys Works, 2015), who uses external intensive educational programs to ensure high quality education in their projects, while their external partners are using Genesys Works' innovative method for seeking talent in underestimated geographical areas. The same is true for both Essay Gifts and Farmers school - these social enterprises unite a number of small enterprises (Essay Gifts 2016) and are eager to distribute innovation between them in case the same challenges come around. For example, Farmers school launches a number of small farms after education, and these farmers come to share their innovative experience to school, so they are later used by new spin-off farms (Shkola fermerov 2016).

Table 1 Cases in open innovation implemented by social business

\begin{tabular}{|c|c|c|c|}
\hline Number & $\begin{array}{l}\text { Social } \\
\text { business }\end{array}$ & $\begin{array}{l}\text { Country of } \\
\text { origin }\end{array}$ & Open innovation model use \\
\hline 1 & $\begin{array}{l}\text { Genesys } \\
\text { Works }\end{array}$ & USA & $\begin{array}{l}\text { The company finds prospective engineers among underprivileged } \\
\text { schoolchildren and educates them by using IT companies' facilities and } \\
\text { educators }\end{array}$ \\
\hline 2 & $\begin{array}{l}\text { Grameen } \\
\text { Danone }\end{array}$ & $\begin{array}{l}\text { Bangladesh, } \\
\text { France }\end{array}$ & $\begin{array}{l}\text { The company uses Danone developed yogurt recipe to provide poor } \\
\text { children in Bangladesh with healthy food. The recipe is developed in } \\
\text { collaboration of Danone and Grameen group }\end{array}$ \\
\hline 3 & Essay Gifts & South Africa & $\begin{array}{l}\text { Essay Gifts collaborates with a number of grassroots enterprises in South } \\
\text { Africa, and spreads knowledge and existing technologies among them if } \\
\text { they are producing same or similar products }\end{array}$ \\
\hline 4 & $\begin{array}{l}\text { Farmers } \\
\text { school }\end{array}$ & Russia & $\begin{array}{l}\text { The company involves farmers and spreads the technologies they } \\
\text { develop to teenagers coming out of prison, provides them with a } \\
\text { platform to start their own farming business and then involves them in } \\
\text { education of others }\end{array}$ \\
\hline
\end{tabular}


We have also find a number of cases where the social businesses relied solely on their own developments (for example, Alternative Energies in South Africa or Bumper in Russia), but their development rate was a lot lower than the rate of social enterprises which used open innovation.

On the basis of qualitative comparative case study analysis (cases were selected crossnationally) we outline, that social businesses, like conventional ones, also use one of the two approaches towards innovation development - either open or formal closed one. The difference of social business model is that social entrepreneurs use open innovation concept much more frequently than conventional entrepreneurs, thus building flat-structured sustainable business models.

Case study have also indicated, that business models used by social business, are in majority of situations based on some sort of grass root innovation, developed within the concept of open innovation (though not necessarily along the formal line for social innovation). On the opposite, only a few cases where social enterprises business models were based on formal closed innovation development process. Besides, there were a number of cases, including Grameen Danone case, when closed innovation was used on the first step of social business development, then proceeded to the stage of open innovation when technology was shared between the initiator company and its partner companies to create better social value with higher level of economic efficiency.

Similar findings were achieved by cluster analysis which was performed on country level. Our target independent variable was rate of nascent social entrepreneurial activity (as measured by GEM), while a few variables which are considered related to social entrepreneurship development level were tested for the same countries. The results of cluster analysis can be seen in Table 2 .

The cluster analysis was followed by regression analysis with share of open innovation products used as independent variable. The models with the highest significance can be seen on Fig. 2 ( $\mathrm{R}$ squared for linear model is .426, for cubic model - .458).

The Fig. 2 indicates that open innovation is related to social entrepreneurs activity, and the relationship is relatively strong. This fact allowed us to form a matrix mapping social entrepreneurs on efficiency/innovation types matrix (analogue of the one present on Fig. 1), which can be seen on Fig. 3.

As it is shown in the Fig. 3, the majority of highly efficient enterprises that rely on open innovation are social enterprises, or enterprises with a very high level of corporate

Table 2 Final centers of clusters

\begin{tabular}{|c|c|c|c|c|}
\hline & \multicolumn{4}{|c|}{ CLuster } \\
\hline & 1 & 2 & 3 & 4 \\
\hline Social entrepreneurship activity rate & 2,97 & 1,65 & 5,11 & 4,54 \\
\hline Share of rural population & 19,29 & 27,71 & 14,60 & 24,00 \\
\hline Share of shadow economy & 22,54 & 23,31 & 14,80 & 59,50 \\
\hline Failed state index & 41,10 & 73,97 & 35,34 & 83,15 \\
\hline Share of open-innovation based products produced by social businesses & 26,93 & 28,39 & 75,74 & 66,70 \\
\hline
\end{tabular}

As it can be seen from the analysis, higher share of open innovation based products indicates higher level of social entrepreneurs' activity (clusters 3 and 4, which include Finland, US, Peru, Argentina and a few others). At the same time other indicators are opposite in these two clusters: for cluster 4 failed state index is rather high, while for cluster 3 it is the lowest; same different results appear to be in case of rural population (some researchers consider higher share of rural population to be driving social business) or failed state and shadow economy (these factors were also seen as indicators of underdeveloped institutions which are related to incentives of social enterprise creation) 


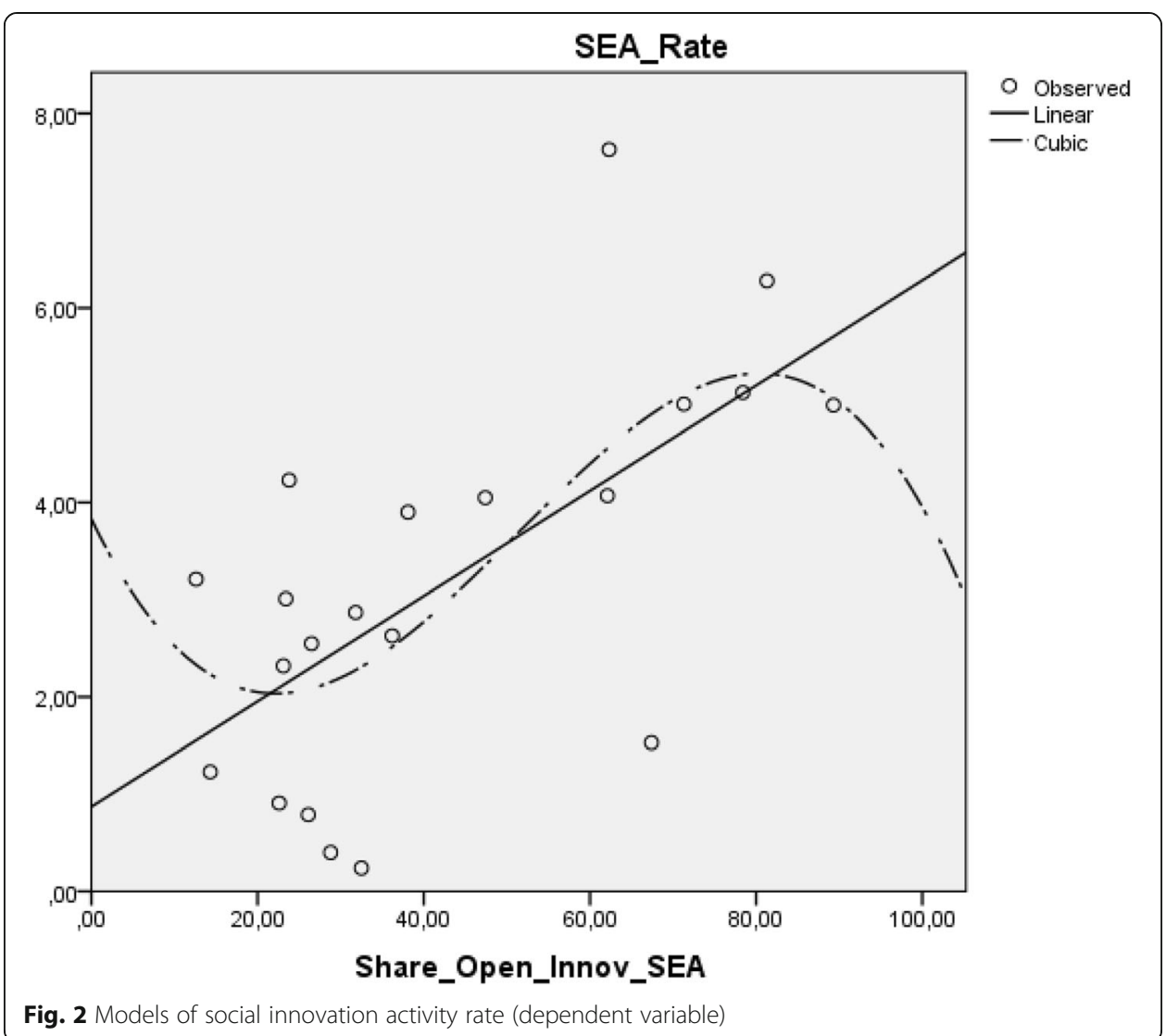

social responsibility ( $0 ; 9$ on the matrix). On the opposite, conventional enterprises are highly efficient, but tend to use closed innovation in the majority of cases (marked 9;9 on the matrix at the extreme).

Open innovation basement is also used by non-profits, but these companies demonstrate lower level of efficiency, than both conventional and social entrepreneurs (mapped 0;0 in the matrix). Finally, public sector enterprises are less efficient than

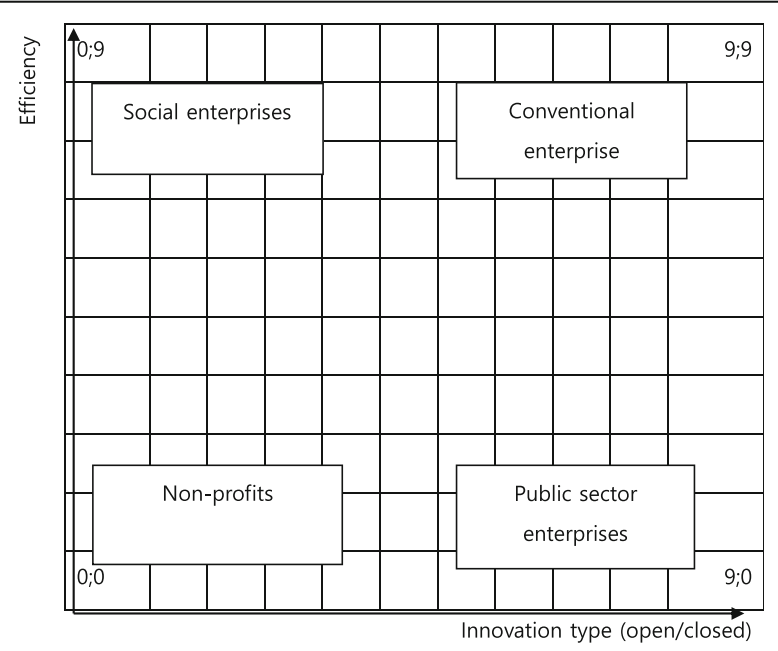

Fig. 3 Matrix of businesses with social mission by efficiency/innovation type (developed by the authors) 
conventional ones, and they also tend to rely on their own developments rather than implement open innovation concept (9;0 on the matrix).

These mapping was suggested by the analyzed case studies, which have not shown any low-efficient businesses with social outcome in case the concept of open innovation was implemented (the above described cases of Genesys Works or Grameen Danone can be used as an example). On the opposite, companies relying on closed innovation had much less interest in social outcomes and could be considered conventional ones.

Thus, we have mapped social businesses on efficiency/innovation type matrix (an analogue of Blake-Mouton matrix), where these businesses are indicated as either low or high efficient and using open innovation or closed innovation concept. Case studies are mapped on the matrix, and the majority of social enterprises which work for over five years appear to be of high efficiency and use open innovation.

\section{Research limitations/ implications}

The main limitations of the study include relatively small sample used for case study. Second, though the sample is cross-cultural, business practices from the regions which have strong tradition on social entrepreneurship (for example, African countries besides South Africa) are underrepresented in the GEM sample and our case study data due to limited access to the data on these companies. Third, the limitations of the study are driven from the use of case method, which might lead to some distortion of theoretical findings.

The main implications of the study include the following. First, it is outlined that efficient social business normally use open innovation concept for innovation development (in many cases in a form of grass root innovation). Hence it is important for a new social business to try to follow this path in innovation development process. This finding supports the theoretical input of open innovation theory by Chesbrough \& Vanhaverbeke (2006) by proving positive outcomes of open innovation in a different setting the case of social enterprises. Thus our research indicates that open innovation theory can possibly be implemented in public and non-profit sector, which would allow achieving higher efficiency in these areas, where enterprises' sustainability is significant to achieve long-term goals.

Second, the tools for evaluation social enterprises perspectives accordingly to used innovation development process are suggested, and their use is justified, which lead to better prognosis of social entrepreneurship development. Thus, it was shown that the highest entrepreneurial activity ratio in social business is achieved when the share of open innovation is between 60 and $85 \%$, which means closed innovation mechanisms are also driving efficiency in the area; however, open innovation concepts are to be prevailing (corresponding matrix on efficiency/ innovation types scales, which is a theoretical implementation of this finding, is present on Fig. 3). A practical outcome of this finding is that in case social enterprises receive any type of governmental or other support, the funders are to ensure implementation of open innovation concept in the social enterprise that should lead to higher efficiency and to shorter payback periods, accordingly. 


\section{Acknowledgements}

This research was conducted in the framework of the project 5.2.7 of National Research Program EKOSOC-LV. The publishing of this paper was supported by SOItmC and the DGIST R\&D Program of the Ministry of Science, ICT and Future Planning (16-IT) of Korea.

\section{Availability of data and materials}

The dataset used for this study might be requested from the authors due to university policy.

\section{Authors' contribution}

AA developed the theoretical framework of the study. KO had studied cases presented in the manuscript. AZ had done statistical analysis. All authors read and approved the final manuscript.

\section{Competing interests}

The authors declare that they have no competing interests.

\section{Author details}

${ }^{1}$ Economics and Management Department, Chistopol autonomous campus, Kazan National Research Technical University, Kazan, Russia. ${ }^{2}$ Faculty of Engineering Economics, Riga Technical University, Riga, Latvian.

\section{Received: 12 July 2016 Accepted: 29 September 2016}

Published online: 12 October 2016

\section{References}

Ashoka. (2014). The Story of Ashoka. Retrieved on December $29^{\text {th }}$, 2014. http://www.youtube.com/watch?v=RfiY9rRsWqE.

Austin, J., Stevenson, H., \& Wei-Skillern, J. (2006). Social and commercial entrepreneurship: same, different or both? Entrepreneurship Theory and Practice, 30(1), 1-22.

Benkler, Y. (2006). The Wealth of Networks: How Social Production Transforms Markets and Freedom. New Haven: Yale University Press.

Carillo, F. H. (2015). Knowledge-based development as a new economic culture. Journal of Open Innovation: Technology, Market, and Complexity, 2015, 1

Chesbrough, H. 2003. Open Innovation: The New Imperative for Creating and Profiting from Technology. Harvard Business Press.

Chesbrough, H., \& Vanhaverbeke, W. (2006) Open Innovation: Researching a New Paradigm. Oxford: Oxford University Press. pp. 1-14.

Dacin, P., Dacin, T., \& Matear, M. (2010). Social Entrepreneurship: Why We Don't Need a New Theory and How We Move Forward From Here. Academy of Management Perspectives, 24(3), 37-57.

de Soto, H. (2000). The Mystery of Capital: Why Capitalism Triumphs In the West and Fails Everywhere Else. New York: Basic Books.

Dees, J. (2001). The Meaning of Social Entrepreneurship. Original draft 1998, revised 2001. Retrieved December $28^{\text {th }}, 2014$ https://entrepreneurship.duke.edu/news-item/the-meaning-of-socialentrepreneurship/.

Driver, M. (2012). An Interview with Michael Porter: Social Entrepreneurship and the Transformation of Capitalism Academy of Management Learning and Education, 1(3), 421-431.

Essay Gifts. (2016). Stories. Retrieved June 16 ${ }^{\text {th }}, 2016$. http://www.essaygifts.co.za/story.php.

Estrin, S., Mickiewicz, T., \& Stephan, U. (2013). Entrepreneurship, social capital, and institutions: Social and commercial entrepreneurship across nations. Entrepreneurship Theory and Practice, 37(3), 479-504.

Genesys Works. (2015). Our concept. Retrieved December 27th, 2015 http://www.techrepublic.com/article/genesysworks-provides-economicallychallenged-students-with-opportunities-in-it/.

Grameen Creative Lab (2014). Retrieved on December $16^{\text {th }}$. http://www.grameencreativelab.com/a-concept-toeradicate-poverty/7-principles.html.

Hockerts, K. (2006). Entrepreneurial Opportunity in Social Purpose Business Ventures. London: Palgrave Macmillan.

Kim S., Kim E., Suh Y., Zheng Z. (2016). The effect of service innovation on R\&D activities and government support systems: the moderating role of government support systems in Korea. Journal of Open Innovation: Technology, Market, and Complexity

Kirzner I. (1978). Competition and Entrepreneurship. Chicago: University of Chicago Press.

Leadbeater, C. (1997). The Rise of Social Entrepreneurship. London: Demos. Retrieved December 30 ${ }^{\text {th }}, 2014$. http://www. demos.co.uk/files/theriseofthesocialentrepreneur.pdf.

Mair, J., \& Marti, I. (2006). Social Entrepreneurship Research: A Source of Explanation, Prediction and Delight. Journal of World Business, 41(1), 36-44.

Masetti, B. (2008). The social entrepreneurship matrix as a "tipping point" for economic change. Emergence: Complexity and Organization. edition 1. doi:10.emerg/10.17357.a78a8a22a573f663377e98cc17f0a1d9.

Montgomer, A. Dacin, P. Dacin, M. T. 2012. Collective Social Entrepreneurship: Collaboratively Shaping Social Good. Journal of Business Ethics, 111, pp. 375-388.

Partzsh, L., Ziegler, R. 2011. Social entrepreneurs as change agents: a case study on power and authority in the water sector. International environmental agreements: politics, law and economics, 11, pp. 63-83.

Peattie, K. Morley, F. 2008. Eight paradoxes of the social enterprise research agenda, Social Enterprise Journal, Vol. 4 Iss: 2. pp. 91-107.

Porter, M., \& Cramer, M. (2011). Creating Shared Value. Harvard Business Review, January, 2011. Retrieved December $15^{\text {th }}$, 2014. https://hbr.org/2011/01/the-big-idea-creating-shared-value.

Roberts, D., Woods, C. 2005. Changing the World on a Shoestring: The Concept of Social Entrepreneurship. University of Auckland Business Review (Autumn), pp. 45-51.

Santos, F.M. (2012). A Positive Theory of Social Entrepreneurship. Journal of Business Ethics, 111(3), 335-351. 
Schumpeter, J. (1934). The Theory of Economic Development: An Inquiry Into Profits, Capital, Credit, Interest, and the Business Cycle. Transaction Publishers

Schwab Foundation. (2016). Retrieved February $8^{\text {th }}$, http://www.schwabfound.org/.

Shkola fermerov. (2016). Story of Success. Retrieved June $18^{\text {th }}, 2016$ http://www.shkolafermerov.ru/pressa.html.

Skoll Foundation. (2016) Retrieved on February $8^{\text {th }}$, http://www.skollfoundation.org/about/.

Stephan, U., Uhlaner, L., Stride, C. 2014. Institutions and Social Entrepreneurship: The Role of Institutional Voids, Institutional Support, and Institutional Configurations. Journal of International Business Studies. Retrieved on January 5th, 2015. http://www.palgravejournals.com/jibs/journal/vaop/ncurrent/full/jibs201438a.html\#t4.

Sud, M., VanSandt, C., \& Baugos, A. (2009). Social Entrepreneurship: the Role of Institutions. Journal of Business Ethics, 85, 201-216.

Terjesen, S., Lepoutre, J., Justo, R., \& Bosma, N. (2009). Global Entrepreneurship Monitor 2009 Report on Societal Entrepreneurship. Retrieved January $5^{\text {th }}, 2015$ www.gemconsortium.org.

Thomson, J., Alvy, G., Lees, A. 2000. Social Entrepreneurship - a New Look at the People and the Potential. Management Decision. No. 38. pp. 328-338.

Timmons, J., Spinelli, S. (1990). New Venture Creation: Entrepreneurship for the XXI century. New York: McGraw-Hill/Irwin

Urbano, D., Toledano, N., \& Soriano, D. (2010). Analyzing Social Entrepreneurship from the Institutional Perspective: Evidence from Spain. Journal of Social Entrepreneurship, 1(1), 54-69.

Waddock, S., \& Post, J. (1991). Social Entrepreneurs and Catalytic Change. Public Administration Review, 51(5), 393-401. Yun J., Won D., Park K. (2016). Dynamics from open innovation to evolutionary change. Journal of Open Innovation: Technology, Market, and Complexity.

Yunus, M. (2008). Creating a World without Poverty: Social Business and the Future of Capitalism. New York: Public Affairs. Yusr M. (2016). Innovation capability and its role in enhancing the relationship between TQM practices and innovation performance. Journal of Open Innovation: Technology, Market, and Complexity. 2:6. doi:10.1186/s40852-016-0031-2.

Zahra, S., Gedajlovic, E., Neubaum, D., \& Schulman, J. (2009). A Typology of Social Entrepreneurs: Motives, Search Processes and Ethical Challenges. Journal of Business Venturing, 24(5), 519-532.

\section{Submit your manuscript to a SpringerOpen ${ }^{\circ}$ journal and benefit from:}

- Convenient online submission

- Rigorous peer review

- Immediate publication on acceptance

- Open access: articles freely available online

- High visibility within the field

- Retaining the copyright to your article

Submit your next manuscript at $\gg$ springeropen.com 